\title{
ST-elevációs miokardiális infarktus szív mágneses rezonanciás jellegzetességei az akut szakban és utánkövetés során. A mikro- vaszkuláris obstrukció prognosztikus szerepe
}

\author{
Czimbalmos Csilla, Csécs Ibolya, Tóth Attila, Suhai Ferenc Imre, Dohy Zsófia, \\ Szabó Liliána Erzsébet, Bárczi György, Zima Endre, Becker Dávid, \\ Merkely Béla*, Vágó Hajnalka*
}

Semmelweis Egyetem, Városmajori Szív- és Érgyógyászati Klinika, Budapest

Levelezési cím:

Dr. Czimbalmos Csilla, 1122 Budapest, Városmajor u.68. E-mail: csilla.czimbalmos@gmail.com

\begin{abstract}
Bevezetés: Miokardiális infarktusban a szív mágneses rezonancia (CMR) vizsgálat szövetspecifikus információt nyújtva alkalmas a szívizom-nekrózis/hegszövet, illetve a mikrovaszkuláris obstrukció (MVO) megítélésére, továbbá a bal és jobb kamra volumenek, ejekciós frakciók, izomtömegek meghatározásának referenciamódszere. Prospektív vizsgálatunk célja ST-elevációs miokardiális infarktus (STEMI) CMR jellegzetességeinek tanulmányozása volt az akut szakban, illetve utánkövetés során, valamint a mért paraméterek prognosztikus szerepének vizsgálata.

Betegek és módszer: 12 órán belüli, első STEMI miatt végzett percutan koronária-intervenciót követően 104 konszekutív betegnél (69 férfi, 35 nö; $60 \pm 12$ év) végeztünk CMR-vizsgálatot az akut szakban (2-4. nap) és 4-6 hónappal azt követően $(n=82)$. Az utánkövetés során súlyos adverz eseménynek a halálozást, illetve a kardiális okból bekövetkező hospitalizációt tekintettük. Rövid- és hossztengelyi síkokban EKG szinkronmozgó-, T2 súlyozott és késői típusú kontraszthalmozásos felvételeket készítettünk. A bal (LV) és jobb kamravolumenek, ejekciós frakciók (EF), izomtömeg, a nekrózis, hegszövet, illetve MVO kvantifikálását végeztük.

Eredmények: Az akut vizsgálat során mért nekrózis $(26,2 \pm 17,0 \mathrm{~g})$ szignifikáns pozitív korrelációt mutatott a CK-MB értékével $(r=0,52)$, valamint negatív korrelációt az akut szakban mért LVEF-fel $(r=-0,40)$. A miokardiális infarktus krónikus szakában végzett CMR-vizsgálat során meghatározott bal kamrai paraméterek szignifikánsan változtak az akut értékekhez képest $(p<0,001)$. A LVEF $(47,3 \pm 9,7 \%$ vs. $51,2 \pm 11,6 \%)$, illetve a bal kamrai végdiasztolés volumenindex $\left(88,3 \pm 20,9 \mathrm{ml} / \mathrm{m}^{2}\right.$ vs. $\left.96,4 \pm 23,0 \mathrm{ml} / \mathrm{m}^{2}\right)$ és a verővolumen-index $\left(41,3 \pm 7,1 \mathrm{ml} / \mathrm{m}^{2}\right.$ vs. $\left.47,3 \pm 7,7 \mathrm{ml} / \mathrm{m}^{2}\right)$ növekedett. A bal kamrai izomtömegindex csökkent $(73,7 \pm 16,9 \mathrm{~g}$ vs. $66,2 \pm 14,3 \mathrm{~g})$, ezen belül a hegszövet zsugorodott $(26,2 \pm 17,1 \mathrm{~g}$ vs. $18,4 \pm 13,1 \mathrm{~g})$. Az akut felvételeken a betegek $36 \%$-ában volt MVO azonositható. Az átlagos $602 \pm 204$ napos utánkövetés során 27 betegnél lépett fel súlyos adverz esemény. Az akut szakban jelenlévő MVO mérete és a későbbi súlyos adverz esemény pozitív összefüggést mutatott $(p<0,05)$.

Következtetések: A CMR-vizsgálat az akut miokardiális infarktust követően kialakuló kamrai remodeling, illetve életképesség megítélésén túl az akut stádiumban jelenlévő - prognosztikus szereppel bíró - MVO kimutatására és kvantifikálására alkalmas noninvazív módszer.
\end{abstract}

Kulcsszavak: akut miokardiális infarktus, kardiális remodelling, mágneses rezonanciás vizsgálat, mikrovaszkuláris obstrukció 
Cardiac magnetic resonance characteristics of ST-segment elevation myocardial infarction in the acute period and during long-term follow up - prognostic role of microvascular obstruction

Cardiac magnetic resonance imaging (CMR) provides tissue-specific information by assessment of myocardial necrosis/scar and microvascular obstruction (MVO), moreover it is the gold standard method of evaluation of left and right ventricular volumes, ejection fractions and mass. The aim of the study was to evaluate the CMR characteristics of ST-elevation myocardial infarction in the acute phase and during follow-up, and the correlation between CMR parameters and adverse cardiac events during the follow-up period.

104 patients (69 male, 35 female; $60 \pm 12$ years) were examined with CMR after percutaneous coronary intervention because of STEMI within 12 hours in the acute phase $\left(2-4^{\text {th }}\right.$ day) and after $4-6$ months $(n=82)$. During the follow-up adverse event was regarded as mortality caused by any reason and hospitalisation because of cardiac causes. In long and short-axis planes ECG synchronized cine movie, T2-weighted spectral inversion recovery (SPIR), and delayed contrast enhancement (DE) images were taken. Left and right ventricular volumes, ejection fractions (EF), mass, myocardial necrosis, MVO and scar tissue were evaluated.

We demonstrated a strong, positive correlation between acute scar extent and level of CK-MB ( $r=0.52)$, and negative correlation between acute scar extension and acute left ventricular ejection fraction (LVEF)( $r=-0,40)$. The left ventricular parameters at follow-up CMR changed significantly ( $p<0,001)$ : LVEF $(47.3 \pm 9.7 \%$ vs. $51.2 \pm 11.6 \%)$, left ventricular end diastolic volume index (LVEDVi) $\left(88.33 \pm 20.9 \mathrm{ml} / \mathrm{m}^{2} \mathrm{vs} .96 .4 \pm 23 \mathrm{ml} / \mathrm{m}^{2}\right)$ and stroke volume index (SVi) $(41.3 \pm 7.1 \mathrm{ml} /$ $\mathrm{m}^{2}$ vs. $\left.47.3 \pm 7.7 \mathrm{ml} / \mathrm{m}^{2}\right)$ increased. Left ventricular mass index (LVMi) $(73.7 \pm 16.9 \mathrm{~g}$ vs. $66.2 \pm 14.3 \mathrm{~g})$ decreased and the scar tissue shrank $(26.2 \pm 17.1 \mathrm{~g}$ vs. $18.4 \pm 13.1 \mathrm{~g})$. MVO was detected in acute phase in $35.6 \%$ of the patients. During the $602 \pm 204$-day follow-up adverse event was detected in 27 patients. We demonstrated positive correlation between the extension of MVO detected in the acute phase and adverse event $(p<0.05)$.

CMR is an outstanding noninvasive method, which helps us in the evaluation of myocardial viability and ventricular remodeling after acute myocardial infarction, moreover in the detection and quantification of MVO, which prognostic role was proved in this study.

Keywords: acute myocardial infarction, cardiac remodeling, magnetic resonance imaging, microvascular obstruction

\section{Bevezetés}

Az akut miokardiális infarktussal kezelt betegek körében a szív mágneses rezonancia vizsgálat (CMR) lehetővé teszi a bal kamrai volumenek, izomtömeg, falvastagság pontos mérését, ezen felül segítségével jól megitélhetők a regionális és globális falmozgászavarok és az esetek egy részében jelenlévő intraventricularis thrombus is. Egyedüli noninvazív vizsgálatként alkalmas az ödéma, nekrózis vagy hegszövet és a mikrovaszkuláris obstrukció (MVO) kiterjedésének pontos meghatározására. Az MVO kialakulásának pontos mechanizmusa máig nem teljesen tisztázott. Létrejöttében szerepet játszik a már az infarktust megelőzően jelen lévő mikrovaszkuláris károsodás, iszkémiás és reperfúziós károsodás, distalis embolizáció és genetikai faktorok (1).

Prospektív vizsgálatunkban célul tüztük ki az STelevációs miokardiális infarktus során létrejövő kardiális változások meghatározását CMR-vizsgálat segítségével. Céljaink között szerepelt az akut miokardiális infarktus CMR jellegzetességeinek meghatározása az akut szakban és utánkövetés során, a CMR-paraméterek és a rutin laborértékek összefüggésének vizsgálata, valamint a klinikai és CMR-pa- raméterek összefüggésének vizsgálata az utánkövetési idő alatt fellépő súlyos adverz események előfordulásával.

\section{Betegek és módszer}

A Városmajori Szív- és Érgyógyászati Klinikán zajló prospektív vizsgálatunkba első, 12 órán belüli ST-elevációs miokardiális infarktuson átesett betegek kerültek bevonásra konszekutív módon. Kizárási kritériumnak tekintettük a súlyos veseelégtelenséget (GFR $<30 \mathrm{ml} /$ min/1,73 $\mathrm{m}^{2}$ ), minden nem MR kondicionális implantátumot, klausztrofóbiát, akut CMR-vizsgálat előtt észlelt súlyos szívelégtelenséget, terhességet és permanens pitvarfibrillációt. Beválasztás előtt minden beteg teljes körủ szóbeli és írásbeli tájékoztatásban részesült, majd beleegyező nyilatkozatot írt alá. A betegek az akut ellátást követően rendszeres kardiológiai gondozásban vettek részt, kardiológiai kontrollvizsgálatra a $30 \pm 7$. napon, a 3. és 6 . hónapban, majd ezt követően 6 havonta került sor. CMR-vizsgálatokat a 2-4. napon, illetve 4-6. hónap között végeztük egy 1,5 Tesla térerejü Philips Achieva típusú MR-berendezéssel. Sorozatos angulálást követő- 


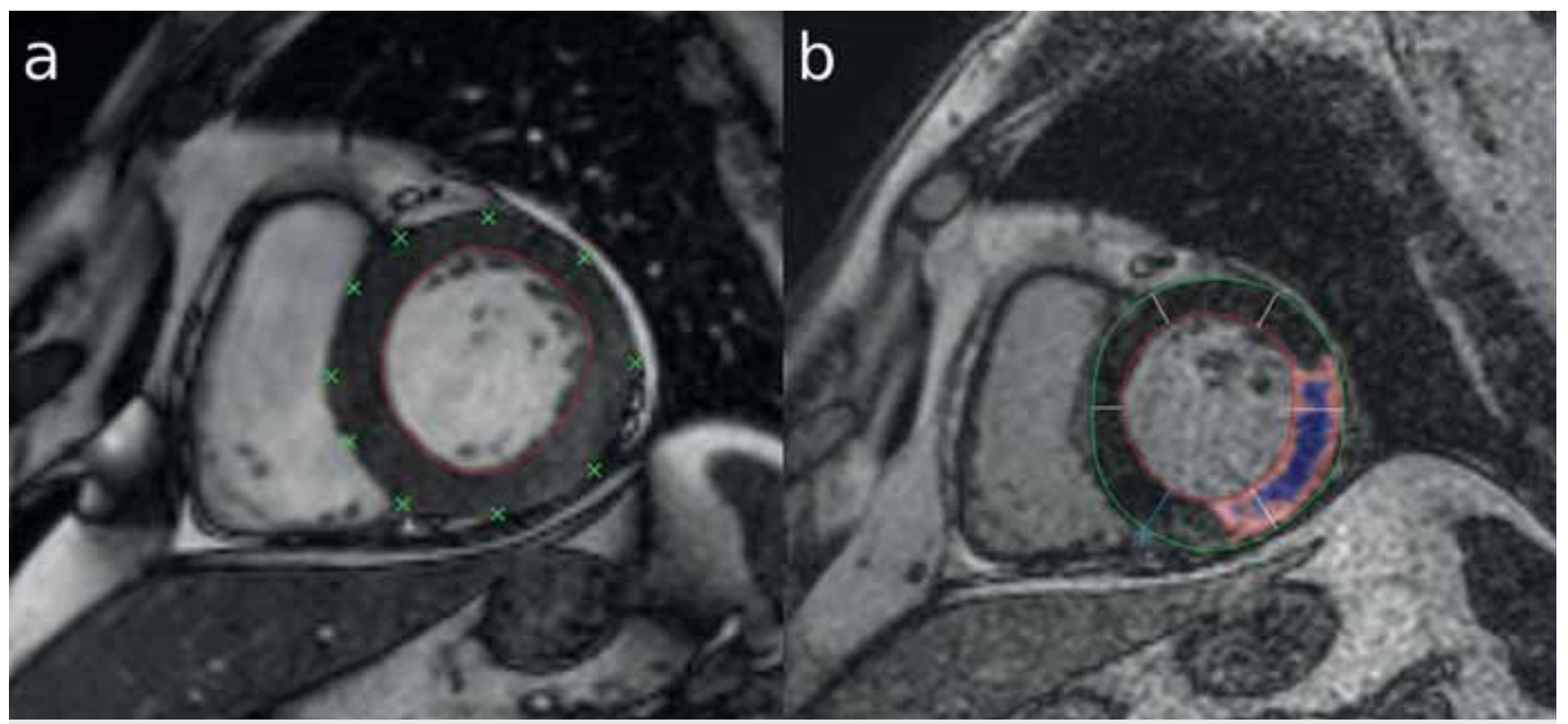

1. ÁBRA. Manuális endo- és epikardiális kontúrozás (a), illetve MVO- és hegkvantifikáció (b)

en hossz- és rövidtengelyi síkokban EKG szinkronmozgó felvételeket, T2-súlyozott spin echo, korai és késői fázisban készült kontrasztanyag-halmozásos felvételeket készítettünk. A kiértékeléséhez a Medis QMass 7.6. (Magnetic Resonance Analytical Software System, Medis Medical Imaging Software, Leiden, The Netherlands) kiértékelő szoftvert használtuk. Manuális endo- és epikardiális kontúrmeghatározást végeztünk mind az akut, mind a kontrollfelvételeken, minden rövidtengelyi szeletben (1. ábra). A szoftver segítségével meghatároztuk a bal és jobb kamrai ejekciós frakciót, a testfelszínre indexált végdiasztolés (LVEDVi) és végszisztolés volument (LVESVi), verővolument (LVSVi) és izomtömeget (LVMi), és kvantifikáltuk a nekrózist/hegszövetet, valamint a mikrovaszkuláris obstrukciót (MVO). Az MVO jelenléte alapján alcsoport-analízist végeztünk. Falvastagság-méréseket végeztünk végdiasztoléban az infarktus által érintett régiókban és ugyanazon rövidtengelyi szeletben a normál szívizom területén mind az akut, mind a késői szakban végzett CMR-felvételeken.

Vizsgáltuk az utánkövetési idő alatt fellépő súlyos adverz eseményeket, amelynek a követési idő során fellépő halálozást vagy kardiális okból bekövetkező rehospitalizációt tekintettük. Rögzítettük a katéteres beavatkozással kapcsolatos adatokat, úgymint az időablakot (az infarktus és a PCl között eltelt idő), az érintett ágakat, a culprit léziót, thrombusaspiráció meglétét vagy hiányát, a beavatkozás előtti, illetve beavatkozás utáni TIMI (Thrombolysis In Myocardial Infarction) flow értéket és az adott integrilin bolus és fenntartó dózisát. A vizsgált laborértékek között szerepelt a CK, a CK-MB, hemoglobin, hematokrit, kreatinin, urea, glomerulus filtrációs ráta (GFR), glükóz és C-reaktív protein (CRP). Vizsgáltuk a kor és nem szerepét, illetve a fennálló társbetegségeket, úgymint a testtömegindex (BMI), fennál- ló diabetes mellitus, hipertónia, hypercholesterinaemia, dohányzás és vesebetegség. Összefüggést kerestünk a súlyos adverz események előfordulása, valamint az általunk meghatározott CMR-paraméterek, a katéteres beavatkozással kapcsolatos adatok, laborértékek, társbetegségek és egyéb klinikai paraméterek között.

A statisztikai számítások során az akut és kontrollvizsgálat során mért értékeket egymintás t-próbával, illetve Wilcoxon-próbával, az alcsoportokat kétmintás t-próbával, nem normáleloszlás esetén Mann-Whitney-U-teszttel hasonlítottuk össze. A korrelációkhoz Spearman-féle korrelációs tesztet alkalmaztunk. Az egyes paraméterek súlyos adverz eseményekkel való összefüggését Cox-regresszióval vizsgáltuk. A p<0,05 értéket tekintettük statisztikailag szignifikánsnak. A statisztikai analízishez IBM SPSS szoftvert használtunk.

\section{Eredmények}

Száznégy, 12 órán belüli ST-elevációs miokardiális infarktusos beteg (69 férfi, 35 nő, 60 12 év) CMR-vizsgálatát végeztük el az akut szakban (2-4. napon), illetve közülük 82 betegnél kontroll CMR-vizsgálat is készült a 4-6. hónapban. A kardiovaszkuláris rizikófaktorok gyakoriságát az 1. táblázatban tüntettük fel.

Az időablak átlagosan $3,4 \pm 1,5$ óra volt, a culprit lézió 55,8\%-ban $(n=58)$ a LAD-on, 36,5\%-ban $(n=38)$ a RCA-n, 6,7\%-ban $(n=7)$ az arteria circumflexán (CX) volt fellelhető. Egy betegnél a koronarográfia során nem találtak culprit léziót, de a CMR-vizsgálat lezajlott miokardiális infarktust igazolt. A betegek 7,7\%-a három ág betegnek, 28,9\%-a pedig két ág betegnek bizonyult. $A z$ utánkövetés alatt statint és $\beta$-blokkolót minden beteg szedett, ACE-gátlót a betegek 93,3\%-a kapott. Egy 


\begin{tabular}{|c|c|}
\hline Férfinem & $66,3 \%(69)$ \\
\hline Életkor (év) & $60 \pm 12$ \\
\hline Diabetes mellitus & $18,3 \%(19)$ \\
\hline Hipertónia & $78,8 \%(82)$ \\
\hline Hypercholesterinaemia & $59,6 \%(62)$ \\
\hline Dohányzás & $31,7 \%(33)$ \\
\hline BMI 25-30 & $44,2 \%(46)$ \\
\hline $\mathrm{BMI}>30$ & $19,2 \%(20)$ \\
\hline
\end{tabular}

beteg kivételével (csak aszpirin) mindannyian kettős trombocitaaggregáció-gátlás alatt álltak, amely aszpirin és clopidogrel $(90,4 \%)$, illetve aszpirin és prasugrel $(8,6 \%)$ adásából állt.
A kontroll CMR-vizsgálat során meghatározott bal kamrai paraméterek szignifikánsan változtak az akut értékekhez képest (2. táblázat). A bal kamrai ejekciós frakció, végdiasztolés volumen, végdiasztolés volumenindex, verővolumen és verővolumen-index növekedett a követési idő során. A bal kamrai izomtömeg, izomtömegindex, nekrózis/hegszövet ezzel szemben csökkent. Az infarktus területén mért falvastagság a kontroll CMR során szignifikánsan alacsonyabb volt, mint közvetlenül a miokardiális infarktus után. Az akut vizsgálatnál mért nekrózis tömege $(26,2 \pm 17 \mathrm{~g})$ szignifikáns pozitív korrelációt mutatott a CK-MB értékével $(p<0,001$; $r=0,523)$, valamint negatív korrelációt az akut szakban mért bal kamrai ejekciós frakcióval $(p<0,001 ; r=-0,404)$. Bal kamrai thrombust 5 betegnél $(4,8 \%)$ találtunk, amely minden esetben novum - az előzőleg elvégzett echokardiográfia során nem ábrázolódó - eltérés volt,

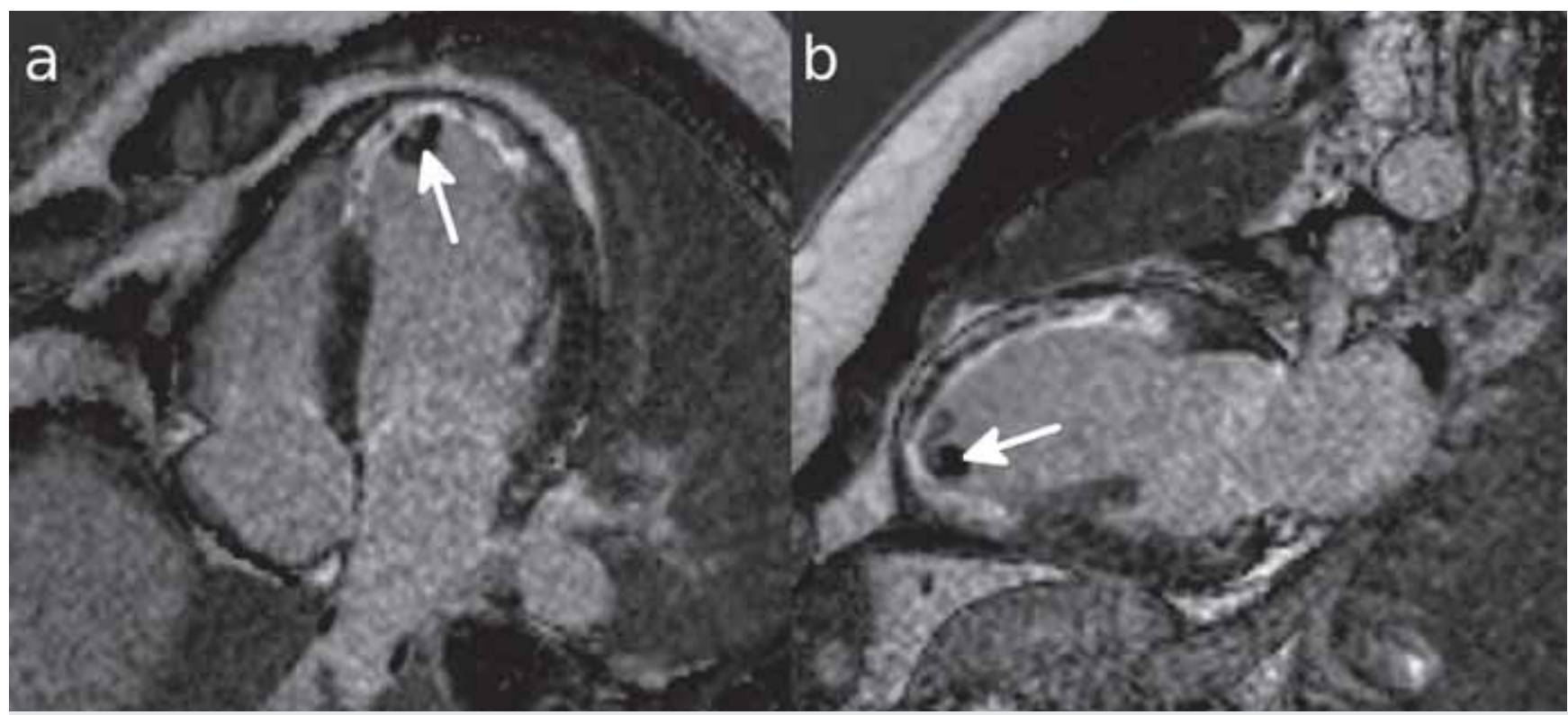

2. ÁBRA. Négy- (a) és kétüregű hossztengelyi síkokban készült késői kontrasztanyag-halmozásos PSIR (phase-sensitive inversion recovery) MR-felvételek három nappal LAD területi infarktust követően. A bal kamra csúcsában kis tapadó thrombus ábrázolódik (b)

2. TÁBLÁZAT. Bal kamrai CMR-paraméterek az akut szakban és a kontroll MR-vizsgálat idején

\begin{tabular}{|c|c|c|c|}
\hline & $\begin{array}{c}\text { Akut vizsgálat } \\
\text { (2-4. nap) }\end{array}$ & $\begin{array}{l}\text { Kontrollvizsgálat } \\
\text { (4-6. hónap) }\end{array}$ & $\mathrm{p}$ \\
\hline LVEF (\%) & $47,3 \pm 9,7$ & $51,2 \pm 11,6$ & $<0,001$ \\
\hline LVEDV (ml) & $169 \pm 39,1$ & $181,3 \pm 45,3$ & $<0,001$ \\
\hline LVEDVi $\left(\mathrm{ml} / \mathrm{m}^{2}\right)$ & $88,3 \pm 20,9$ & $96,4 \pm 23$ & $<0,001$ \\
\hline LVSV (ml) & $77,7 \pm 15,6$ & $89,7 \pm 19$ & $<0,001$ \\
\hline LVSVi $\left(\mathrm{ml} / \mathrm{m}^{2}\right)$ & $41,3 \pm 7,1$ & $47,3 \pm 7,7$ & $<0,001$ \\
\hline LVM (g) & $137,4 \pm 34,3$ & $124,5 \pm 29$ & $<0,001$ \\
\hline LVMi $\left(g / m^{2}\right)$ & $73,7 \pm 16,9$ & $66,2 \pm 14$ & $<0,001$ \\
\hline Nekrózis/hegszövet (g) & $26,2 \pm 17,1$ & $18,4 \pm 13,1$ & $<0,001$ \\
\hline Falvastagság az infarktus területén (mm) & $10,9 \pm 2,5$ & $6,9 \pm 1,7$ & $<0,001$ \\
\hline $\begin{array}{l}\text { Falvastagság a normál myocardium } \\
\text { területén }(\mathrm{mm})\end{array}$ & $7,3 \pm 1,7$ & $7,2 \pm 1,6$ & ns \\
\hline
\end{tabular}




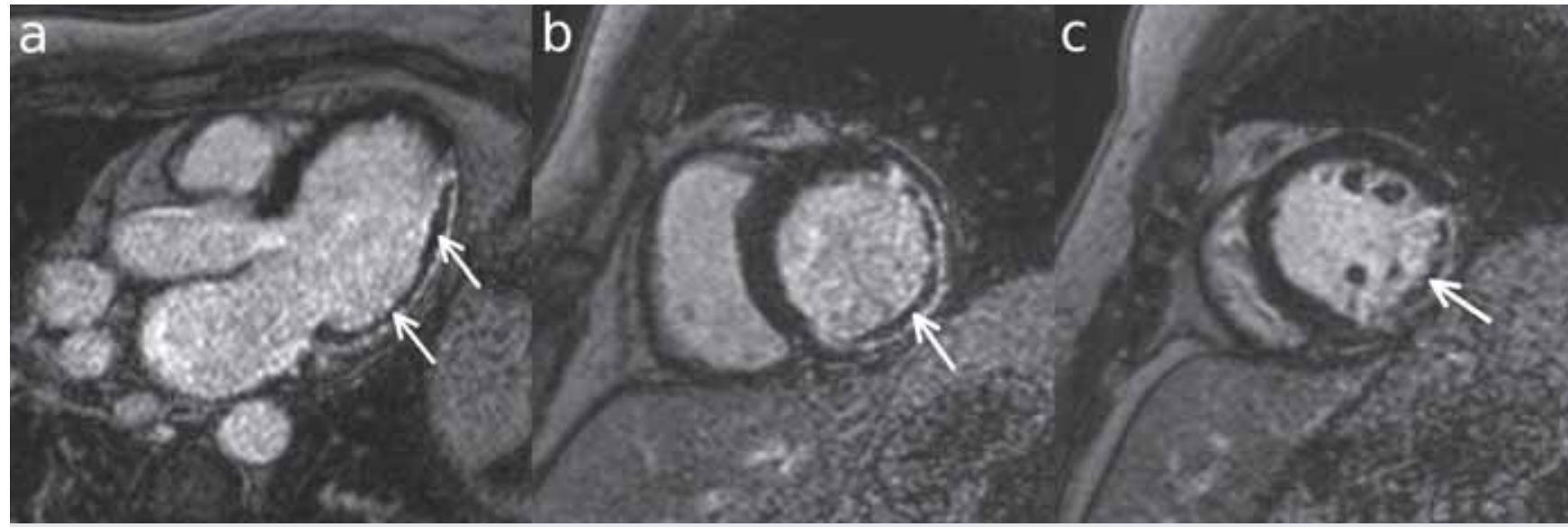

3. ÁBRA. Késői kontrasztanyag-halmozásos MR-felvételek hossz- (a) és rövidtengelyi síkokban (b, c) két nappal az akut miokardiális infarktust követően. A CX ellátási területének megfelelően magas jelintenzitással ábrázolódó nekrózis és annak centrumában alacsony jeladású mikrovaszkuláris obstrukció látható

és LAD-infarktus kapcsán alakult ki (2. ábra). Mind az 5 betegnél az akut szakban fordult elő, de egy esetben a kontrollvizsgálatok során is találtunk intraventricularis thrombust. Az akut felvételeken a betegek 35,6\%-ában volt MVO azonosítható (3. ábra). Az átlagos 602 \pm 204 napos utánkövetés során 27 betegnél lépett fel valamilyen súlyos adverz esemény. Közülük 15 betegnél miokardiális infarktus, hat esetben újonnan jelentkező szívelégtelenség, három esetben de novo pitvarfibrilláció, két esetben malignus kamrai ritmuszavar, egy betegnél pedig stroke miatt történt hospitalizáció. Halálozás két esetben történt. Az általunk vizsgált összes koronarográfiás adat, laborérték, fennálló társbetegség, illetve egyéb klinikai paraméter közül csak az akut szakban jelenlévő MVO és az érintett koszorúerek száma mutatott összefüggést a későbbi súlyos adverz események jelenlétével $(p<0,05)$. A beavatkozás utáni TIMI-3-as flow-val rendelkező betegek 36,5\%-ánál jelen volt a bal kamra tömegének 1\%-át meghaladó MVO. Az
MVO-val rendelkező betegek körében az akut vizsgálat során szignifikánsan alacsonyabb ejekciós frakciót, magasabb nekrózistömeget és magasabb bal kamrai izomtömeget mértünk, mint MVO nélküli betegek körében. A kontrollszakban mért ejekciós frakció szintén alacsonyabb volt, míg az LVEDVi, az LVESVi és a hegszövet tömege magasabb volt az MVO-s csoportban (3. táblázat).

\section{Megbeszélés}

Bal kamrai remodelling

Az akut szakban és a 4-6. hónapban végzett CMR-vizsgálat során meghatározott bal kamrai volumenek, úgymint a bal kamrai végdiasztolés volumen, verővolumen és ezek testfelszínre számított értékei szignifikáns eltérést mutattak. A bal kamrai végdiasztolés volumen és végdiasztolés volumenindex a 4-6 hónap során jelentősen emelkedett a remodelling következményeként

\begin{tabular}{|c|c|c|c|c|}
\hline & & MVO-s csoport & MVO nélküli csoport & $\mathrm{p}$ \\
\hline \multirow[t]{7}{*}{ Akut MR } & LVEF (\%) & $43,6 \pm 9,7$ & $48,9 \pm 10,8$ & $<0,05$ \\
\hline & LVEDVi $\left(\mathrm{ml} / \mathrm{m}^{2}\right)$ & $93,6 \pm 21,6$ & $86,1 \pm 24,1$ & ns \\
\hline & LVESVi $\left(\mathrm{ml} / \mathrm{m}^{2}\right)$ & $54,1 \pm 21,9$ & $46,7 \pm 21,8$ & ns \\
\hline & Nekrózis (g) & $34,9 \pm 18,6$ & $19,1 \pm 17$ & $<0,001$ \\
\hline & $\operatorname{LVMi}\left(\mathrm{g} / \mathrm{m}^{2}\right)$ & $151,1 \pm 58,8$ & $131,2 \pm 36$ & $<0,05$ \\
\hline & Falvastagság - infarktus (mm) & $10,6 \pm 2,3$ & $11,1 \pm 2,7$ & ns \\
\hline & Falvastagság - ép myocardium (mm) & $7,1 \pm 1,9$ & $7,6 \pm 1,5$ & ns \\
\hline \multirow[t]{6}{*}{ Kontroll MR } & LVEF (\%) & $46,9 \pm 10$ & $55,4 \pm 11,6$ & $<0,001$ \\
\hline & LVEDVi $\left(\mathrm{ml} / \mathrm{m}^{2}\right)$ & $103,7 \pm 21,8$ & $89,5 \pm 22,2$ & $<0,01$ \\
\hline & LVESVi $\left(\mathrm{ml} / \mathrm{m}^{2}\right)$ & $56,7 \pm 22,8$ & $41,9 \pm 23,3$ & $<0,01$ \\
\hline & Hegszövet (g) & $24,3 \pm 11,9$ & $12,9 \pm 11,8$ & $<0,001$ \\
\hline & Falvastagság - infarktus (mm) & $6,8 \pm 1,6$ & $7 \pm 1,8$ & ns \\
\hline & Falvastagság - ép myocardium (mm) & $6,7 \pm 1,3$ & $7,8 \pm 1,6$ & $<0,01$ \\
\hline
\end{tabular}




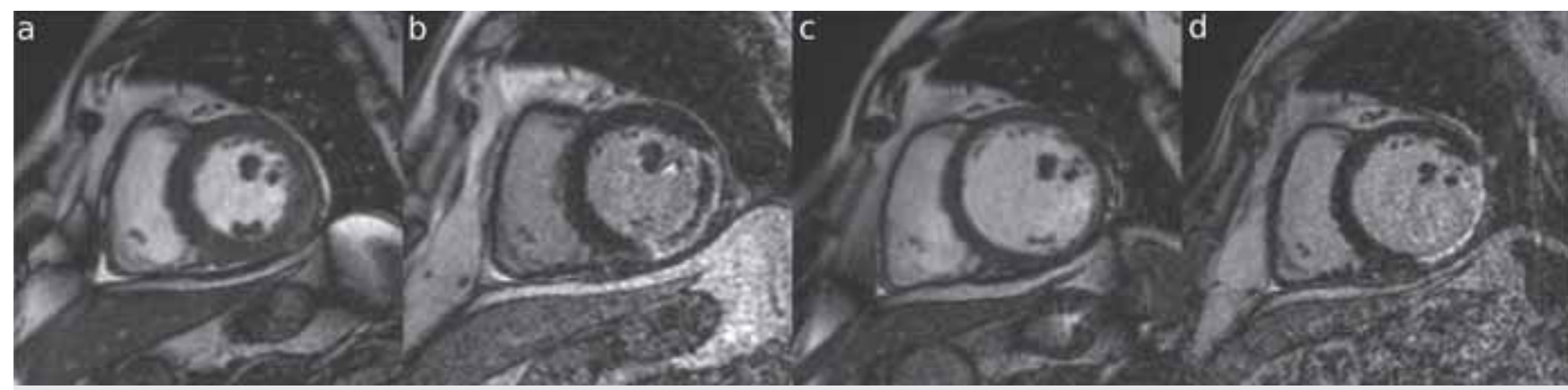

4. ÁBRA. Rövidtengelyi mozgófelvételek végdiasztolés fázisban $(a, c)$ és késői kontrasztanyag-halmozásos felvételek (b, d) egy akut miokardiális infarktust átvészelő betegnél a harmadik napon ( $a, b)$, valamint 4 hónappal később (c, d). Az akut szakban, illetve a 4 hónappal később készült CMR-felvételek összevetése során szembetűnik a bal kamrai falvastagság csökkenése és a bal kamra tágulata (LVM: $198 \mathrm{~g}$ vs. 149 g; LVEDV: $200 \mathrm{ml}$ vs. $287 \mathrm{ml}$ ). Az infarktus krónikus fázisában mért hegszövet az akut szakban mért 62 g-ról 32 g-ra csökkent, és az akut szakban jelenlévő MVO a kontrollvizsgálat idején már nincs jelen

(4. ábra). A bal kamrai ejekciós frakció, verővolumen és verővolumen-index jelentős emelkedését is megfigyeltük a 4-6 hónapot követően. Chan és társai posztinfarktusos betegek CMR-vizsgálatát végezték az ötödik napon, illetve 6 hónap után, és vizsgálatuk hasonló eredményeket hozott. Az akut szakban mért bal kamrai végdiasztolés volumenindex esetükben is szignifikánsan alacsonyabb volt a későbbi vizsgálat során mérthez képest $\left(85,8 \pm 17\right.$ vs. $\left.97,3 \pm 25 \mathrm{ml} / \mathrm{m}^{2}\right)$. A bal kamrai ejekciós frakció azonban abban a betegcsoportban nem mutatott jelentős javulást $(50,2 \pm 7$ vs. $51,2 \pm 13 \%)$. $A z$ értékeket egy egészséges kontrollcsoport paramétereivel is összevetették, az ejekciós frakció magasabb $(66,6 \pm 6 \%)$, a végdiasztolés volumen $\left(77 \pm 17 \mathrm{ml} / \mathrm{m}^{2}\right)$ alacsonyabb volt a kontrollcsoportban, mint a posztinfarktusos betegek körében (2). Az LVEF javulásának elmaradását magyarázhatja, hogy akut szívelégtelen betegek is bevonásra kerültek.

A saját vizsgálatunk során meghatározott bal kamrai izomtömeg és izomtömegindex az akut szakban szignifikánsan magasabb volt, ami a miokardiális infarktust követően az akut szakban jelen lévő ödémával magyarázható. A korai fázisban az infarktus által érintett myocardium tömege és falvastagsága az akut gyulladás, haemorrhagia és ödéma következtében megnövekszik. Idővel az akut szakban még jelenlévő ödéma felszívódik, majd az infarktus fokozatosan heggé alakul át, ami a késői kontrasztanyag-halmozás méretének csökkenésében nyilvánul meg. Az akut felvételeken jelen lévő bal kamrai nekrózis tömege szignifikánsan magasabb volt, mint a miokardiális infarktus krónikus szakában mért hegszövet tömege. Az akut szakban Chan és munkacsoportja is szignifikánsan magasabb infarktustömeget mért, mint 6 hónappal az infarktus után $(28,6 \pm 19$ vs. $16 \pm 8 \mathrm{~g})$.

Az akut szakban és a második CMR-vizsgálat során mért falvastagságokat összevetve az infarktus területén jelentős falvastagság-csökkenést találtunk. Ennek hátterében az akut szakban jelenlévő ödéma felszívódása, valamint a nekrózis heggé alakulása állhat. A miokardi- ális infarktust követően fellépő bal kamrai remodelling során változások mennek végbe a kamra méretét, alakját és funkcióját tekintve. A korai fázisban az infarktus által érintett myocardium tömege és falvastagsága az akut gyulladás, haemorrhagia és ödéma következtében megnövekszik. Idővel az akut szakban még jelenlévő ödéma felszívódik, majd a nekrotikus szövet fibrotikus heggé való folyamatos átalakulása figyelhető meg, ami az infarktus méretének csökkenésében nyilvánul meg. A myocardium elvékonyodása az akut szakban nagy MVO-t mutató területeken kifejezettebb. A bal kamrai remodelling dilatációval jár, a heg területén csökken a falvastagság, a növekvő falfeszülés következtében excentrikus hipertrófia figyelhető meg. Ezek a változások krónikus szívelégtelenség kialakulásához vezethetnek.

\section{Bal kamrai thrombus}

A rendszeres kardiológiai kontroll alatt álló betegek körében a CMR-vizsgálat 4,8\%-ban mutatott ki újonnan felfedezett kamrai thrombust, amely minden esetben LAD-infarktust követően alakult ki. Ennek oka valószínűleg, hogy a kisebb csúcsi, illetve tapadó fali thrombusok echokardiográfiával sok esetben nehezen hozhatók látótérbe. Habár az utóbbi évtizedekben a bal kamrai thrombusképződés gyakorisága posztinfarktusos betegekben - feltehetöleg az agresszívebb antikoagulációs terápia, a kisebb infarktusok, és a mérsékeltebb bal kamrai remodelling miatt - szignifikánsan csökkent, anterior AMI esetén azonban gyakoriságuk napjainkban sem elhanyagolható. Egy több mint 8000 fös post STEMI-s vizsgálat eredményei alapján az akut szakban 5,1\%-ban találtak bal kamrai thrombust, és anterior STEMI esetén szignifikánsan gyakrabban találtak thrombust, mint egyéb infarktusok esetén (11,5\% vs. 2,3\%) (3). Ezek az adatok echokardiográfiával detektált thrombusokról szólnak, ám a CMR-vizsgálat nagyobb szenzitivitású a nonkontraszt echokardiográfiához képest. Egy 243 esetszámú vizsgálatban a késői kontrasztanyag-halmozásos CMR-képeken detektált thrombusoknak majdnem kétharmadát nem diagnosz- 
tizálták echokardiográfiával. Az echokardiográfiával fel nem ismert thrombusok döntően kisméretű, tapadó fali thrombusok (4).

\section{Mikrovaszkuláris obstrukció}

Az MVO a reperfúziós károsodás hátterében álló egyik jelenség, irodalmi adatok alapján a STEMI-t túlélt betegek több mint felében jelen van (5). Kialakulásában szerepet játszhat a mikrovaszkulatúra iszkémiás károsodása, a kialakuló szöveti ödéma következtében az endothel endoluminaris protrúziója, mikroembolizáció, oxidatív szabad gyökök képződése és neutrofil, vörösvértest, vérlemezke, illetve fibrindepozitumok képződése (6). Nem egyértelmű, hogy mely betegcsoportokban kell számítanunk az MVO kialakulására, de a $\mathrm{PCl}$ során végzett thrombusaspiráció, az időablak hossza és a heg transmuralitása egyaránt összefügghet az MVO jelenlétével $(7,8)$. Az MVO a hosszú távú kimenetel független prediktoraként segíthet a rizikóstratifikációban.

A koronarográfiák során leírt alacsony TIMI grade flow utalhat a mikrovaszkulatúra károsodására. Irodalmi adatok alapján TIMI 3 flow esetén a mortalitás sokkal alacsonyabbnak bizonyult, mint kisebb TIMI flow értékek esetén, habár TIMI 3 flow-val jellemzett koronarográfiával rendelkező betegek akár felében is kialakulhat $\operatorname{MVO}(9,10)$. A mikrovaszkulatúra károsodását jóval pontosabban jelzik az invazív nyomásmérés során nyert paraméterek, mint a CFR (coronary flow reserve), vagy az IMR (index of microcilculatory resistance). Az MVO kvantitatív meghatározására jelenleg egyedül alkalmas noninvazív módszer a CMR-vizsgálat. Léteznek ugyan egyéb, kevésbé specifikus és szenzitív módszerek, amelyekkel az MVO detektálható, úgymint a reziduális ST-eleváció, vagy a kontraszt echokardiográfia. A kontraszt echokardiográfia a korlátozott térbeli felbontás, vizsgáló függőség és a bal kamra laterális falának szuboptimális megjelenítése miatt az MVO-meghatározás céljából a mindennapi gyakorlatban nem terjedt el (11). Ezzel szemben a kontrasztanyag adásával végzett CMR-vizsgálat jó térbeli felbontás mellett képes ábrázolni a bal kamra bármely szegmentumában elhelyezkedő MVO-t, és annak kiterjedése is nagy pontossággal meghatározható. A kontrasztanyag beadása és a felvételek készítése között eltelt idő alapján megkülönböztetjük az ún. korai, illetve a késői fázisban meghatározott MVO-t. A korai fázisban meghatározott MVO pár perccel a kontrasztanyag adását követően válik láthatóvá. A normál myocardium és az infarktus által érintett terület is magas jelintenzitással képeződik le, de az MVO területére a kontrasztanyag nem jut be, így alacsony szignálintenzitás jellemzi. A késői fázisban meghatározott MVO megjelenítésére, majd kvantifikálására a késői kontrasztanyag-halmozásos képek alkalmasak. Kb. 10-15 perccel a kontrasztanyag beadása után az infarktus által érintett myocardiumon belül felhalmozódik a kontrasztanyag, és a lassabb kimosódás miatt magas jelintenzitással ábrázolódik, szemben az alacsony jel- intenzitású normál myocardiummal. Amennyiben MVO is jelen van, az típusosan a nekrotikus terület centrumában elhelyezkedő alacsony jelintenzitású területként ábrázolódik. STEMI-s betegek körében a késői fázisban meghatározott MVO jelenléte és kiterjedése fontos prognosztikai faktornak bizonyult a primer kompozit végpontok tekintetében, úgymint a mortalitás, miokardiális infarktus és szívelégtelenség (12). Irodalmi adatok alapján az MVO az akut miokardiális infarktust követö második napon még jelen van, de az esetek jelentős részében egy hét elteltével eltünik (13). Az MVO megítélése céljából végzett $C M R$-vizsgálat elvégzése tehát az akut szakban (2-4. napon) ajánlott, és a kvantifikálására a késői kontrasztanyag-halmozásos felvételek a legalkalmasabbak.

\section{MVO és súlyos adverz események}

Eredményeink alapján a STEMI-s betegek kimenetelét az általunk vizsgált katéteres, labor-, klinikai és CMR-paraméterek közül egyedül az érintett koronáriák száma, illetve az MVO jelenléte határozta meg. Eszerint a 2-4. napon CMR-vizsgálat segítségével meghatározott MVO jelenléte független prediktor a későbbiekben fellépő súlyos adverz események tekintetében. Irodalmi adatok alapján az MVO prevalenciája STEMI-t követően 46-78\% (14-16). Az általunk vizsgált betegek között 35,6\%-ában volt jelen MVO. Feltételezzük, hogy a relatíve alacsony $\mathrm{MVO}$-előfordulás azzal magyarázható, hogy a legrosszabb állapotú betegek, reanimáltak, vagy akut szívelégtelenek kizárásra kerültek.

A közelmúltban több kutatás is céljául tűzte ki az MVO és a hosszú távú kimenetel, illetve a bal kamrai remodelling összefüggésének vizsgálatát. Kimutatták, hogy az akut szakban jelenlévő MVO a hosszú távú kimenetelt rontja, illetve a remodellinggel is összefüggést mutat. MVO-val rendelkező betegcsoportban alacsonyabb ejekciós frakciót, magasabb bal kamrai volumeneket, nagyobb infarktusméretet találtak. Az utóbbi években újabb nagy, multicentrikus klinikai vizsgálatok és metaanalízisek igazoltál a mikrovaszkuláris obstrukció prognosztikus szerepét mind a rövid, illetve hosszú távú mortalitás és szívelégtelenség miatti hospitalizáció tekintetében. A CMR-vizsgálatok és az utánkövetés során fellépő súlyos adverz események (halál, reinfarktus, stroke, újabb revaszkularizáció, iszkémiás tünetek viszszatérte, pitvarfibrilláció, szívelégtelenség miatti hospitalizáció) alapján megállapították, hogy MVO jelenléte esetén gyakrabban léptek fel súlyos adverz események. Az MVO-s betegeknél nagyobb infarktusméretet és alacsonyabb ejekciós frakciót találtak. Az akut szakban ábrázolódó MVO bizonyult a legerősebb független prediktornak a hosszú távú kimenetel tekintetében $(17,18)$.

\section{Az MVO hátterében álló tényezők és az MVO megelózése}

Felvetődik a kérdés, hogy milyen befolyásolható tényező áll az MVO kialakulásának hátterében, és hogyan 
lehetne csökkenteni az MVO-val rendelkező betegek számát, illetve az MVO kiterjedését. Esetünkben az időablak nem mutatott összefüggést az MVO kialakulásával, azonban a $\mathrm{PCl}$ során végzett thrombusaspirációt követően gyakrabban volt jelen MVO, mint thrombusaspiráció hiányában ( $71 \%$ vs. $50 \%)$. Ez az eredmény felveti az aspiráció során okozott mikroembolizáció szerepét az MVO kialakulásában, azonban jelen vizsgálatban a betegeket nem randomizáltuk thrombusaspiráció szerint. Thrombusaspirációt az intervenciós kardiológusok a trombotikusabb léziók esetén végeztek, ez utóbbi hozzájárulhat a nagyobb kiterjedésű MVO kialakulásához. Irodalmi adatok alapján MVO ritkábban fordul elő thrombusaspiráción átesettek körében, sőt a thrombusaspirációt mint az MVO-t megelőző faktorként is említik. Egy kis esetszámú vizsgálat alapján STEMI-t követően a primer $\mathrm{PCl}$ során végzett thrombusaspiráció kisebb miokardiális ödémával, kisebb miokardiális haemorrhagiával, mérsékelt bal kamrai remodellinggel és ritkább MVO előfordulással járt (19). Egy másik vizsgálatban thrombusaspirációs és thrombusaspiráció nélküli csoportba randomizált posztinfarktusos betegek $\mathrm{CMR}$-vizsgálatát végezték el. A primer $\mathrm{PCl}$ során végzett thrombusaspiráció szignifikánsan csökkentette az MVO kiterjedését és a miokardiális diszfunkció mértékét, de a bal kamrai remodellingre nem volt jótékony hatással (20). Habár a thrombusaspiráció csökkentheti az MVO kiterjedését, a STEMI-ben végzett thrombusaspiráció hatását vizsgáló nagy multicentrikus prospektív randomizált klinikai vizsgálatok alapján a thrombusaspiráció nem javítja a klinikai kimenetelt. Nagy thrombotikus léziók esetén csökkentheti a kardiovaszkuláris halálozást, de nagyobb stroke-rizikóval járhat (21-23). Az Európai Kardiológus Társaság legfrissebb ajánlása alapján a rutinszerű thrombusaspiráció nem ajánlott, de nagy reziduális trombotikus léziók esetén alkalmazása megfontolandó (24). A reperfúziós károsodás mértékének csökkentését számos kutatás tűzte ki céljául. Igazolt tény, hogy a hosszú távú statin, vagy béta-blokkoló előkezelés hozzájárul a mikrocirkuláció protekcióhoz (25-27). Az MVO kialakulásának megelőzését célzó katéteres laborban alkalmazott eljárások közé tartozik a nagy dózisú adenozin intrakoronárias adása, intenzíven vizsgált terület továbbá az iszkémiás pre-, poszt- és remote kondicionálás alkalmazása is $(28,29)$.

\section{Következtetések}

A CMR-vizsgálat kiválóan alkalmas az akut miokardiális infarktust követően kialakuló kamrai remodelling, illetve életképesség megítélésére. Továbbá lehetőséget nyújt az akut stádiumban jelenlévő mikrovaszkuláris obstrukció nonivazív kimutatására és kvantifikálására, ezáltal nagy szerepet kap a mikrovaszkuláris károsodás csökkentését célzó újabb terápiák hatékonyságának felmé- résében. A CMR-vizsgálat a klinikai vizsgálatokon túl a kardiológiai gyakorlatban is egyre szélesebb körben alkalmazott képalkotó modalitásként nagyban hozzájárulhat a ST-elevációs miokardiális infarktusos betegek pontosabb rizikóstratifikációjához.

\section{Támogatók, köszönetnyilvánítás}

Az NVKP 16-1-2016-0017 számú projekt a Nemzeti Kutatási Fejlesztési és Innovációs Alapból biztosított támogatással, az NVKP_16 pályázati program fi nanszírozásában valósult meg. Az Emberi Erőforrások Minisztériuma ÚNKP-18-3-IV kódszámú Új Nemzeti Kiválóság Programjának támogatásával készült.

\section{Irodalom}

1. Niccoli G, Scalone G, Lerman A, Crea F. (Coronary microvascular obstruction in acute myocardial infarction. Eur Heart J 2016; 37(13):1024-1033 DOI:10.1093/eurheartj/ehv484.

2. Chan W, Duffy SJ, White DA, Gao XM, Du XJ, Ellims AH, et al. Acute left ventricular remodeling following myocardial infarction: coupling of regional healing with remote extracellular matrix expansion. JACC Cardiovasc Imaging 2012; 5(9): 884-893. DOI:10.1016/j. jcmg.2012.03.015

3. Chiarella F, Santoro E, Domenicucci S, Maggioni A, Vecchio C. Predischarge two-dimensional echocardiographic evaluation of left ventricular thrombosis after acute myocardial infarction in the GISSI-3 study. Am J Cardiol 1998; 81(7): 822-827.

4. Goyal P, Weinsaft JW. Cardiovascular magnetic resonance imaging for assessment of cardiac thrombus. Methodist Debakey Cardiovasc J 2013; 9(3): 132-136

5. Klug G, Mayr A, Schenk S, Esterhammer R, Schocke M, Nocker $\mathrm{M}$, et al. Prognostic value at 5 years of microvascular obstruction after acute myocardial infarction assessed by cardiovascular magnetic resonance. J Cardiovasc Magn Reson 2012; 14: 46. DOI:10.1186/1532-429X-14-46.

6. Bekkers SC, Yazdani SK, Virmani R, Waltenberger J. Microvascular obstruction: underlying pathophysiology and clinical diagnosis. J Am Coll Cardiol 2010; 55(16): 1649-1660. DOI:10.1016/j. jacc.2009.12.037

7. Nakano M, Otsuka F, Finn AV, Virmani R. Microvascular obstruction is caused by atherothrombosis in patients with acute coronary syndrome undergoing percutaneous coronary intervention. Circ Cardiovasc Imaging 2011; 4(6): 597-600. DOI:10.1161/CIRCIMAGING.111.969683

8. Yang Y, Graham JJ, Connelly K, Foltz WD, Dick AJ, Wright GA. MRI manifestations of persistent microvascular obstruction and acute left ventricular remodeling in an experimental reperfused myocardial infarction. Quant Imaging Med Surg 2012; 2(1): 12-20. DOI:10.3978/j.issn.2223-4292.2011.12.02.

9. Brener SJ, Moliterno DJ, Aylward PE, van't Hof AW, Ruzyllo W, O'Neill WW, et al. Reperfusion after primary angioplasty for ST-elevation myocardial infarction: predictors of success and relationship to clinical outcomes in the APEX-AMI angiographic study. Eur Heart J 2008; 29(9): 1127-1135. DOI:10.1093/eurheartj/ehn125.

10. Gibson CM, Cannon CP, Daley WL, Dodge JT, Jr., Alexander B, Jr., Marble SJ, et al. TIMI frame count: a quantitative method of assessing coronary artery flow. Circulation 1996; 93(5): 879-888.

11. Porter TR, Li S, Oster R, Deligonul U. The clinical implications of no reflow demonstrated with intravenous perfluorocarbon containing microbubbles following restoration of Thrombolysis In Myocardial Infarction (TIMI) 3 flow in patients with acute myocardial infarction. Am J Cardiol 1998; 82(10): 1173-1177. 
12. de Waha S, Desch S, Eitel I, Fuernau G, Zachrau J, Leuschner A, et al. Impact of early vs. late microvascular obstruction assessed by magnetic resonance imaging on long-term outcome after ST-elevation myocardial infarction: a comparison with traditional prognostic markers. Eur Heart J 2010; 31(21): 2660-2668. DOI:10.1093/eurheartj/ehq247.

13. Orn S, Manhenke C, Greve OJ, Larsen AI, Bonarjee VV, Edvardsen $\mathrm{T}$, et al. Microvascular obstruction is a major determinant of infarct healing and subsequent left ventricular remodeling following primary percutaneous coronary intervention. Eur Heart J 2009; 30(16): 1978-1985. DOI:10.1093/eurheartj/ehp219.

14. Bruder O, Breuckmann F, Jensen C, Jochims M, Naber CK, Barkhausen $\mathrm{J}$, et al. Prognostic impact of contrast-enhanced CMR early after acute ST segment elevation myocardial infarction (STEMI) in a regional STEMI network: results of the "Herzinfarktverbund Essen". Herz 2008; 33(2): 136-142. DOI:10.1007/s00059-008-3102-8.

15. Hombach V, Grebe O, Merkle N, Waldenmaier S, Hoher M, Kochs $\mathrm{M}$, et al. Sequelae of acute myocardial infarction regarding cardiac structure and function and their prognostic significance as assessed by magnetic resonance imaging. Eur Heart J 2005; 26(6): 549-557. DOI:10.1093/eurheartj/ehi147.

16. Kim HW, Farzaneh-Far A, Kim RJ. Cardiovascular magnetic resonance in patients with myocardial infarction: current and emerging applications. J Am Coll Cardiol 2009; 55(1):1-16. DOI:10.1016/j. jacc.2009.06.059.

17. de Waha S, Patel MR, Granger CB, Ohman EM, Maehara A, Eitel I, et al. Relationship between microvascular obstruction and adverse events following primary percutaneous coronary intervention for ST-segment elevation myocardial infarction: an individual patient data pooled analysis from seven randomized trials. Eur Heart J 2017; 38(47): 3502-3510. DOI:10.1093/eurheartj/ehx414.

18. Symons R, Pontone G, Schwitter J, Francone M, Iglesias JF, Barison A, et al. () Long-Term Incremental Prognostic Value of Cardiovascular Magnetic Resonance After ST-Segment Elevation Myocardial Infarction: A Study of the Collaborative Registry on CMR in STEMI. JACC Cardiovasc Imaging 2018; 11(6): 813-825. DOI:10.1016/j.jcmg.2017.05.023.

19. Zia MI, Ghugre NR, Connelly KA, Joshi SB, Strauss BH, Cohen $\mathrm{EA}$, et al. Thrombus aspiration during primary percutaneous coronary intervention is associated with reduced myocardial edema, hemorrhage, microvascular obstruction and left ventricular remodeling. J Cardiovasc Magn Reson 2012; 14: 19. DOI:10.1186/1532429X-14-19.

20. Galiuto L, Garramone B, Burzotta F, Lombardo A, Barchetta S, Rebuzzi AG, et al. Thrombus aspiration reduces microvascular obstruction after primary coronary intervention: a myocardial contrast echocardiography substudy of the REMEDIA Trial. J Am Coll Cardiol 2006; 48(7): 1355-1360. DOI:10.1016/j.jacc.2006.05.059.
21. Frobert O, Lagerqvist B, Olivecrona GK, Omerovic E, Gudnason $\mathrm{T}$, Maeng M, et al. Thrombus aspiration during ST-segment elevation myocardial infarction. N Engl J Med 2013; 369(17): 1587-1597. DOI:10.1056/NEJMoa1308789.

22. Jolly SS, Cairns JA, Yusuf S, Meeks B, Pogue J, Rokoss MJ, et al. Randomized trial of primary $\mathrm{PCl}$ with or without routine manual thrombectomy. N Engl J Med 2015; 372(15): 1389-1398 DOI:10.1056/NEJMoa1415098.

23. Jolly SS, James S, Dzavik V, Cairns JA, Mahmoud KD, Zijlstra F, et al. (Thrombus Aspiration in ST-Segment-Elevation Myocardial Infarction: An Individual Patient Meta-Analysis: Thrombectomy Trialists Collaboration. Circulation 2017; 135(2): 143-152. DOI:10.1161/ CIRCULATIONAHA.116.025371

24. Ibanez B, James S, Agewall S, Antunes MJ, Bucciarelli-Ducci C, Bueno H, et al. 2017 ESC Guidelines for the management of acute myocardial infarction in patients presenting with ST-segment elevation: The Task Force for the management of acute myocardial infarction in patients presenting with ST-segment elevation of the European Society of Cardiology (ESC). Eur Heart J 2018; 39(2): 119-177. DOI:10.1093/eurheartj/ehx393.

25. Zhao JL, Yang YJ, Pei WD, Sun YH, Zhai M, Liu YX, et al. (Carvedilol reduces myocardial no-reflow by decreasing endothelin-1 via activation of the ATP-sensitive K+ channel. Perfusion 2008; 23(2): 111-115. DOI:10.1177/0267659108094628.

26. Iwakura K, Ito H, Kawano S, Okamura A, Kurotobi T, Date M, et al. (Chronic pre-treatment of statins is associated with the reduction of the no-reflow phenomenon in the patients with reperfused acute myocardial infarction. Eur Heart J 2006; 27(5): 534-539. DOI:10.1093/eurheartj/ehi715.

27. Sorrentino SA, Doerries C, Manes C, Speer T, Dessy C, Lobysheva I, et al. Nebivolol exerts beneficial effects on endothelial function, early endothelial progenitor cells, myocardial neovascularization, and left ventricular dysfunction early after myocardial infarction beyond conventional beta1-blockade. J Am Coll Cardiol 2011; 57(5): 601-611 DOI:10.1016/j.jacc.2010.09.037.

28. Botker HE, Kharbanda R, Schmidt MR, Bottcher M, Kaltoft AK, Terkelsen CJ, et al. Remote ischaemic conditioning before hospital admission, as a complement to angioplasty, and effect on myocardial salvage in patients with acute myocardial infarction: a randomised trial. Lancet 2010; 375(9716): 727-734. DOI:10.1016/S01406736(09)62001-8.

29. Baranyai T, Giricz Z, Varga ZV, Koncsos G, Lukovic D, Makkos $A$, et al. In vivo MRI and ex vivo histological assessment of the cardioprotection induced by ischemic preconditioning, postconditioning and remote conditioning in a closed-chest porcine model of reperfused acute myocardial infarction: importance of microvasculature. J TransI Med 2017; 15(1): 67. DOI:10.1186/s12967-0171166-z. 